\title{
UGT1A6 Gene
}

National Cancer Institute

\section{Source}

National Cancer Institute. UGT1A6 Gene. NCI Thesaurus. Code C105572.

This gene is involved in the excretion of phenolic metabolites. 